\title{
Using RADARSAT to Identify Sea Ice Ridges and their Implications for Shipping in Canada's Hudson Strait
}

\author{
Olivia Mussells, ${ }^{1,2}$ Jackie Dawson $^{1}$ and Stephen Howell ${ }^{3}$
}

(Received 19 January 2016; accepted in revised form 30 June 2016)

\begin{abstract}
Ridges in sea ice and the convergent forces that form them are a serious hazard to ships traveling in the Arctic, but few studies have examined ridge distribution at a basin level in the Canadian Arctic. The Hudson Strait, which connects Hudson Bay and the North Atlantic, is a site of ongoing winter shipping where vessels frequently encounter pressured ice conditions and ridging. Here, RADARSAT-1 and RADARSAT-2 ScanSAR Wide images were used to identify ridges manually in a winter shipping corridor in the Hudson Strait for the period 1997 to 2012. Ridge count peaked in the month of March. No significant linear trend in the number of ridges was identified on either a monthly or annual scale, which is the result of great variability from year to year. However, spatial patterns of ridging distribution were evident: ridging occurred primarily in the eastern and western sectors of the study area, both in the region between Charles Island and the Quebec coastline and at the eastern entrance to the Hudson Strait. Seasonal sea level pressure (SLP) patterns from years of high and low ridge density were compared, but consistent correlations between SLP and ridge density were not found. The impacts of one-time storm events on ridge densities were also investigated. More analysis is needed to understand the factors influencing ridge density in the Hudson Strait.
\end{abstract}

Key words: Arctic shipping; pressured ice; ridges; RADARSAT; ice hazards

RÉSUMÉ. Les crêtes de glace de mer et les forces convergentes qui donnent naissance à ces crêtes constituent un grand danger pour les navires naviguant dans l'Arctique. Cependant, peu d'études se sont penchées sur la répartition des crêtes au niveau d'un bassin dans l'Arctique canadien. Le détroit d'Hudson, qui relie la baie d'Hudson à l'Atlantique Nord, est un lieu d'activité maritime constante en hiver, où les navires font souvent face à des conditions de glaces sous pression et à la formation de crêtes. Dans le cadre de cette étude, nous avons utilisé des images de RADARSAT-1 et de RADARSAT-2 ScanSAR Wide afin de repérer les crêtes manuellement dans un couloir de navigation hivernal du détroit d'Hudson pour la période allant de 1997 à 2012. Le nombre de crêtes atteignait son maximum au mois de mars. Aucune tendance linéaire importante quant au nombre de crêtes n'a été déterminée, tant à l'échelle mensuelle qu'à l'échelle annuelle, ce qui est le résultat d'une grande variabilité d'une année à l'autre. Cependant, les profils spatiaux de la répartition des crêtes étaient évidents : la formation de crêtes se produisait principalement dans les secteurs est et ouest de la zone à l'étude, tant dans la région située entre Charles Island et le littoral du Québec qu'au point d'entrée est du détroit d'Hudson. Nous avons comparé les profils de pression saisonnière au niveau de la mer (PNM) pendant les années de forte et de faible densité de crêtes, mais aucune corrélation uniforme n'a été trouvée entre les PNM et la densité des crêtes. Nous avons également examiné les effets d'événements pluviohydrologiques uniques sur la densité des crêtes. Il y a lieu de pousser les analyses plus loin pour comprendre les facteurs qui exercent une influence sur la densité des crêtes dans le détroit d'Hudson.

Mots clés : navigation dans l'Arctique; glace sous pression; crêtes; RADARSAT; glace dangereuse

Traduit pour la revue Arctic par Nicole Giguère.

\section{INTRODUCTION}

Shipping in the Canadian Arctic has increased significantly since 2007 (Pizzolato et al., 2014) and is projected to become more viable in the future (Smith and Stephenson, 2013; Stephenson et al., 2013). While some of the interest in Arctic shipping can be attributed to the decline in sea ice, other factors, such as tourism, community re-supply needs, and increasing resource exploration and extraction activities, are also important drivers (Brigham, 2011). The Hudson Strait (Fig. 1) is an excellent example of a place where all these driving factors are at play. It is an important passage between the North Atlantic Ocean and Hudson Bay, which makes up a section of the Arctic Bridge shipping route between Churchill, Manitoba, Canada, and Murmansk, Russia. Cargo vessels transport goods from the privately operated Port of Churchill through the strait to destinations in eastern Canada and foreign markets

\footnotetext{
${ }^{1}$ Geography Department, University of Ottawa, 60 University, Ottawa, Ontario K1N 6N5, Canada

${ }^{2}$ Corresponding author: omuss074@uottawa.ca

${ }^{3}$ Climate Research Division, Environment Canada, 4905 Dufferin St., Toronto, Ontario M3H 5T4, Canada

(C) Her Majesty the Queen in Right of Canada. Administered by the Arctic Institute of North America
} 


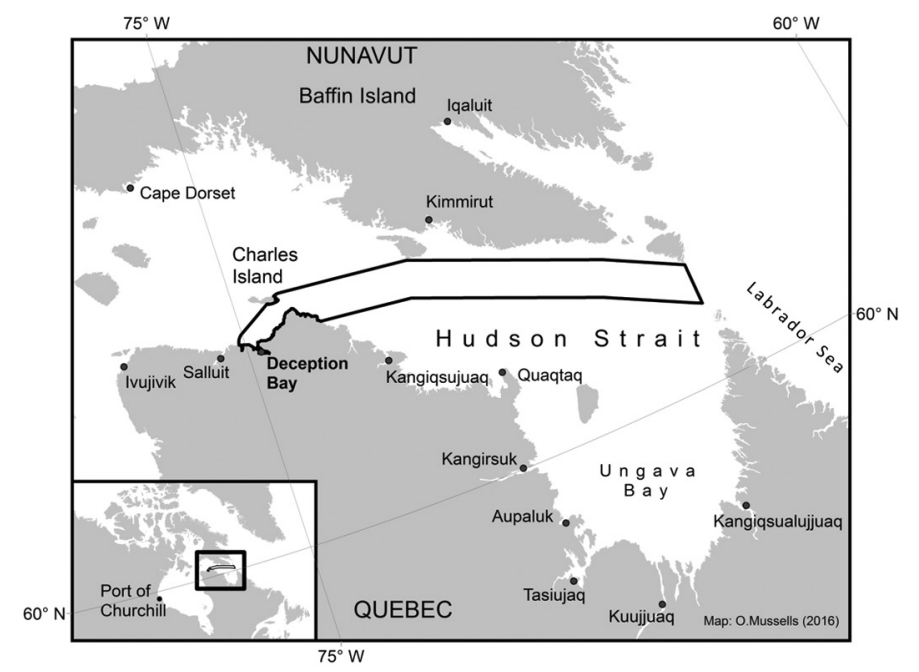

FIG. 1. Map of the Hudson Strait and surrounding region. The winter shipping corridor examined in this study is outlined in black.

(Stewart and Lockhart, 2005). During the summer months, the Hudson Strait is used for as many as three re-supply trips to the communities that line the coast of the strait and Hudson Bay (NEAS, 2014) and forms part of several regular cruise ship routes. Finally, there is the Raglan nickel mine in Deception Bay, Quebec, owned and operated by Xstrata Nickel, which has been serviced year-round since 1998 by an ice-strengthened vessel that has accessed the mine through the Hudson Strait. It is this vessel that has experienced the hazards of pressured ice in the strait throughout the winter months. Resource exploration continues in the region, and proposed mines in mainland Nunavut could lead to even greater year-round ship traffic, meaning a likely increase in the probability that ships will encounter hazardous ice conditions such as pressured and ridged ice.

When ice converges and comes under pressure, it can raft or form ridges (Bradford, 1972; Timco and Burden, 1997; Marchenko, 2008). Rafting occurs when one sheet of ice slides over another; ridges form once ice has become too thick to raft (typically more than $15 \mathrm{~cm}$ thick; Weeks and Kovacs, 1970). Sea ice under pressure and the ridges in the ice that are subsequently formed by the pressure represent some of the most hazardous navigational conditions that ships can encounter while operating in the Arctic region.

The buildup of pressure is usually the result of convergent forces from winds, currents, and tides (Kubat et al., 2012). For example, the icebreaker Louis S. St-Laurent, which escorted the tanker SS Manhattan through the Northwest Passage in 1969, encountered pressured ice during that voyage twice as frequently when wind speeds averaged $21-30$ knots as when winds averaged $0-10$ knots, and it was observed that greater wind speeds brought greater intensity of pressured ice (Bradford, 1972). These forces can be enhanced by bottleneck areas, for example, when ice is pushed between an island and a coastline (Kubat et al., 2012). As the floes come together, blocks of ice break off and are piled up above and below the waterline, forming what are called a sail and a keel, respectively (Marchenko,
2008; Weeks, 2010). Ridges can occur anywhere sea ice is mobile, and it is estimated that about $40 \%-50 \%$ of the entire Arctic Ocean sea ice cover is ridged (Wadhams, 2000; Leppäranta, 2005). Ridge age is described in the same way as sea ice age. First-year ridges, which are the focus of this study, are those that form annually and do not survive the summer melt season. These ridges often have sharp sails that are still visibly made up of blocks of ice, and they are typically less consolidated than multiyear ridges, which have lasted through at least one summer season (Strub-Klein and Sudom, 2012).

Sea ice ridges are an important consideration for shipping, as well as for offshore structures (Obert and Brown, 2011). Ridges can represent the greatest load experienced by a vessel or structure when the ice is mobile enough for them to form (Timco et al., 2000; Gorbunova and Shkhinek, 2015; Vakulenko and Bolshev, 2015). Given the hazard that pressured ice and ridges pose to vessels, it is surprising to find only a very limited number of studies that examine ice under pressure as it relates to shipping in the Canadian Arctic (see Bradford, 1972; Xue et al., 2011; Kubat et al., 2012, 2013). There have been some studies in the Baltic, but these are also limited (see Pärn et al., 2007; Montewka et al., 2015; Valdez Banda et al., 2015). Most of these studies have focused on individual ridge geometry and ridge dimensions for engineering purposes. Few studies have comprehensively examined the distribution of ridges within a geographic area over an extended period of time, but most that have done so have also developed sea ice models that account for ridging and ice deformation (Amundrud et al., 2004; Lipscomb et al., 2007; Sulsky and Peterson, 2011; Mårtensson et al., 2012). Ice ridge distribution has been identified as a knowledge gap within the shipping community: ship captains and operators, when interviewed, have described the need for pressured ice forecasts and for increased availability of information regarding pressured ice distribution (Timco et al., 2005; Kubat and Sudom, 2008).

This work examines ridging patterns in a winter shipping corridor in the Hudson Strait from 1997 to 2012. We created a sea ice climatology for the region in order to understand regional ice patterns. Ridge density patterns were then analyzed spatially across the strait and temporally through the 15 -year time period. Factors affecting ridge formation, including sea level pressure and one-time storm events, were also investigated.

\section{STUDY AREA}

The Hudson Strait serves as a passage between Hudson Bay and the Labrador Sea (Fig. 1). The strait is approximately $400 \mathrm{~km}$ long and has an average width of $150 \mathrm{~km}$. It ranges from 300 to $900 \mathrm{~m}$ in depth (Saucier et al., 2004). The hydrology is heavily influenced by strong tidal currents (the tidal range in Ungava Bay can be as much as $12 \mathrm{~m}$ ), freshwater runoff, local and regional atmospheric forcing, 


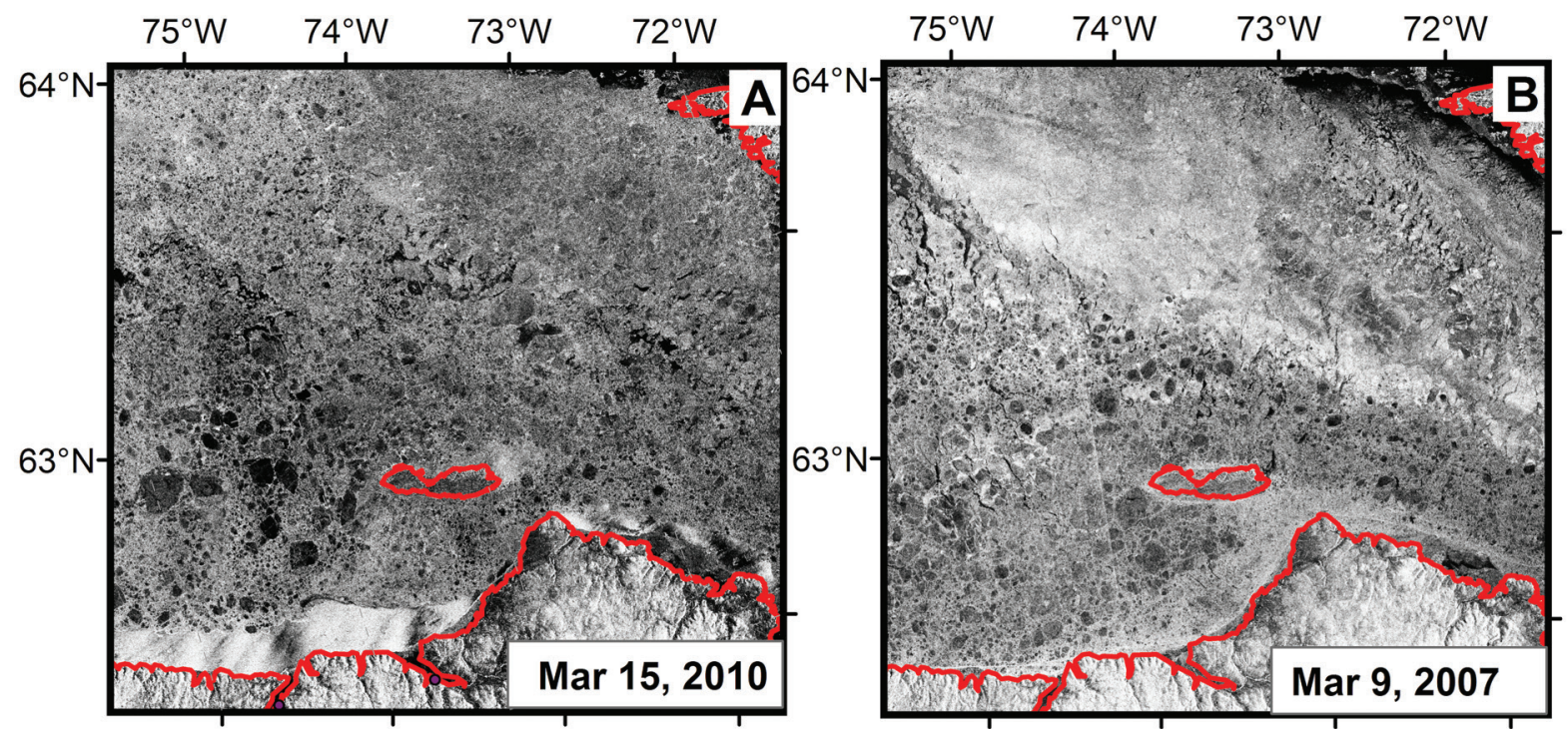

FIG. 2. (A) RADARSAT-2 imagery of low ridge densities and (B) RADARSAT-1 imagery of high ridge densities in the Hudson Strait. Brighter areas and lines denote ridged areas, whereas darker areas indicate smooth surfaces. The coastline is indicated in red. (RADARSAT imagery $\odot$ Canadian Space Agency)

and ocean currents in Baffin Bay, the Labrador Sea, and the Arctic Ocean (Saucier et al., 2004). Currents flow through the strait in opposite directions: the Baffin Island current flows in from Baffin Bay from east to west along the northern coast of the strait, while fresher waters from Hudson Bay travel west to east along the southern coast (Drinkwater, 1986). Overall, there is a net export of water through the Hudson Strait from west to east and out into the North Atlantic (Straneo and Saucier, 2008a).

During the winter months, from January to April, the Hudson Strait is covered in 9/10 to 10/10 of ice (Markham, 1986; CIS, 2011). The average air temperature over these months between 1948 and 2012 was $-14^{\circ} \mathrm{C}$, according to the National Centers for Environmental Prediction (NCEP) reanalysis data (Kalnay et al., 1996). Ice formation begins in the western portion of the strait, which is also the site of ice intrusions from Foxe Basin and the rest of the Arctic, and then spreads eastwards (Crane, 1978). Except for landfast ice along the coasts, the ice in the Hudson Strait remains mobile all winter; leads open and close frequently, and the ice can become heavily ridged by March (Saucier et al., 2004). Markham (1986) observed 6 to 14 ridges per $\mathrm{km}^{2}$, and an average of three ridges per $\mathrm{km}^{2}$ in the strait, although the spatial coverage of the study was limited to six flown transects. A recurring polynya, or area of open water, persists along the southern coast of Baffin Island throughout the winter (CIS, 2011). Ice breakup follows a reverse pattern to ice formation: it begins with the breakup of landfast ice along the coast, which is followed by the movement of the ice out the eastern opening of the strait (Houser and Gough, 2003). The last ice to remain in the strait is in the western sector, where ice continues to intrude from Foxe Basin, and in Ungava Bay, where ice accumulates throughout the winter and becomes highly ridged and rubbled (Houser and Gough, 2003; CIS, 2011).
The Hudson Strait has been used for year-round marine access to the Raglan Mine in Deception Bay since 1998. During these winter voyages, the vessel follows a similar track through the strait (P. Bourbonnais, pers. comm., 28 January 2014). For this study, a shipping corridor through the Hudson Strait based on the typical track of previous voyages by the vessel was selected and is considered to be the winter shipping lane of interest. The corridor that was selected is $40 \mathrm{~km}$ wide and $300 \mathrm{~km}$ long and can be seen outlined in Figure 1. The time frame chosen for this study was December to May, inclusive, these being the months when there is more than 5/10 ice coverage in the strait (CIS, 2011). As these six consecutive months span two calendar years, they will be referred to throughout this paper as the winter shipping season, or simply the season, to avoid confusion.

\section{DATA}

\section{RADARSAT Imagery}

RADARSAT-1 and RADARSAT-2 synthetic aperture radar (SAR) imagery was used in this study to identify the spatial and temporal distribution of sea ice ridges in the Hudson Strait. SAR imagery is useful for monitoring hazardous ice conditions because it is not dependent on solar illumination and therefore is not limited by the polar night. Additionally, microwaves are able to penetrate clouds and are independent of weather conditions. SAR imagery has been widely used to identify pressure ridges (see Vesecky et al., 1990; Melling, 1998; Scheuchl et al., 2004; Kwok et al., 2006; Kwok, 2014). In SAR images, ridges appear as bright white, linear features that are easily discernible from level ice. Examples of highly ridged ice and relatively level ice can be seen in Figure 2. Figure 2A shows an instance 
of less ridging, whereas in Figure 2B the same region can be seen with bright linear features along the coast at the bottom of the image and between the coast and the island. In a study using remote sensing and an in situ field validation campaign, Johnston and Flett (2001) assessed the possibility of using RADARSAT ScanSAR Wide imagery for detecting deformed ice. Despite the difference in scale between sea ice ridge (typically 3.5-4 m wide) and ScanSAR Wide resolution (100 m), Johnston and Flett (2001) concluded that deformed ice could successfully be identified in the RADARSAT images, but that the measurement of the length and width of individual ridges could be troublesome. This conclusion agrees with the results of Melling (1998) and Johnston (2001), who used on-ice field data to validate ridge observation in RADARSAT images. The use of lower-resolution images is advantageous in that they provide larger spatial and temporal coverage (Johnston and Flett, 2001).

There have been some attempts to automate ridge detection in SAR images. For example, Vesecky et al. (1990) used backscatter intensity thresholds and linear feature detection algorithms to isolate ridges in airborne SAR images, with some success. Additionally, work has been carried out to determine threshold values for detecting deformed ice in SAR imagery (Dierking and Dall, 2007). However, given the relatively small geographic area of this study, the inaccuracies associated with automated detection, and the specific focus of this study on ridges rather than deformed ice in general, manual identification of ridges was used.

RADARSAT-1 and RADARSAT-2 ScanSAR wide images $\left(200 \mathrm{~m} \mathrm{pixel}^{-1}\right)$ at $\mathrm{HH}$ (horizontal transmission, horizontal reception) polarization of the Hudson Strait for the period 1997 to 2012 were acquired from the Canadian Ice Service for the months December to May inclusive. Both RADARSAT-1 and RADARSAT-2 operate in the C-band of the electromagnetic spectrum, with center frequencies of $5.3 \mathrm{GHz}$ and $5.405 \mathrm{GHz}$, respectively. The number of images for each season between 1997 and 2011 averaged 53 images, ranging from a minimum of 33 images in 1998-99 to a maximum of 58 images in 2000-01 and 2007-08. However, a sharp rise in the number of images that covered the study region occurred in the 2011-12 season, when 212 images were available. It is not known why there might have been such a large increase in the number of images acquired by the Canadian Ice Service compared to previous years, unless perhaps it was in anticipation of the decommissioning of RADARSAT-1 (CIS, pers. comm. 21 May 2015).

\section{Canadian Ice Service Data Archive}

Sea ice area and concentration in the Hudson Strait were extracted from the Canadian Ice Service Digital Archive (CISDA) (http://iceweb1.cis.ec.gc.ca/Archive/). The CISDA is a collection of CIS's daily operational ice charts, regional ice analysis charts, and weekly ice thickness and on-ice depth measurements. Weekly regional ice charts are available for the Hudson Bay region from 1971 until present. The operational ice charts are created by integrating information from satellite images, ship reports, operational model outputs, and ice forecaster knowledge (CIS, 2011). A complete description of the CISDA can be found in Tivy et al. (2011). We extracted and plotted the average area of ice covering the Hudson Strait each week for the period 1981-2010 in order to understand the typical ice formation patterns in the strait. The dates of ice freeze-up (the first date when more than $50 \%$ of the strait was covered by ice) and breakup (the first date when less than $50 \%$ of the strait was covered by ice) were also derived for each year in order to assess trends in the period of time the Hudson Strait was covered by ice in the winter. Coverage of $50 \%$ is typically used as a threshold for freeze-up and breakup in sea ice studies in the Hudson Strait (e.g., Gagnon and Gough, 2005; Gough and Houser, 2005).

\section{NCEP Reanalysis Monthly Composites}

Factors that might influence ridge formation in the Hudson Strait were investigated using the NCEP reanalysis data provided by NOAA/OAR/ESRL PSD, Boulder, Colorado on their website (http://www.esrl.noaa.gov/psd/ data/gridded/data.ncep.reanalysis.html) (Kalnay et al., 1996). Monthly and seasonal composites of sea level pressure (SLP) at the surface layer were created; both the mean and climatological anomaly (1981-2010) composites were investigated in the area surrounding the shipping corridor and compared to ridge density patterns.

The impacts of severe storm events on ridging patterns were also explored. SLP was used as a proxy for storm events. The NCEP reanalysis data were used to determine the average sea level pressure over the Hudson Strait during the months of interest (December to May). On the basis of the average SLP of $990 \mathrm{mb}$, a threshold of $960 \mathrm{mb}$ was set. When the SLP over the Hudson Strait dropped below $960 \mathrm{mb}$, we considered this drop a severe storm event. The ridging patterns before and after the storm event were examined using RADARSAT imagery in order to determine the impacts of storms on ridging patterns. A window of two days before and two days after the storm event was used when selecting the images to be used for the comparison.

\section{RIDGE DETECTION METHOD}

For each winter season (defined for this study as 1 December to 31 May) between 1997 and 2012, we examined all available RADARSAT images that covered the chosen winter shipping corridor. In each image, ridges were identified visually and digitized manually. Ridges were identified in the images as linear features with high levels of backscatter, thus appearing very bright. The ridges needed to be at least two pixels (i.e., $400 \mathrm{~m}$ ) long to be identified. There is a chance that the same ridges 
might have been counted in two successive images over the same area. However, this is highly unlikely given the great mobility of the ice in the Hudson Strait; the patterns in the ice change drastically between images. The ridges were subsequently tallied on a monthly and a seasonal basis to calculate total annual ridge frequency for each winter season. There is some uncertainty associated with manual identification, as the ridge dimensions (3-4 m wide) are much smaller than the resolution of the images. As well, in areas of heavy ridging it is difficult to discern individual ridges when many have become consolidated. In these areas, some ridges may have been missed, because they were too close to another ridge to be identified.

To understand the temporal distribution of ridging in Hudson Strait, we calculated the number of ridges identified in each winter season. Because the number of images available per season varied, the total ridge count was divided by the number of images available that winter season in order to calculate standardized monthly and seasonal values for ridge count per image. These values were analyzed to determine whether the number of identified ridges per image had decreased or increased between seasons. We calculated mean monthly ridge counts and used linear regression to analyze both monthly and annual ridge count means for trends.

Ridge densities were calculated in order to understand the spatial distribution of ridges in the study area shipping corridor. A grid of $2500 \mathrm{~m} \times 2500 \mathrm{~m}$ cells was overlaid on the study corridor. The $2500 \mathrm{~m}$ scale was selected because it was most relevant to ship navigation, but also because that scale consolidated ridge densities enough for regional patterns in distribution to be identified. Coverage of the shipping corridor by the satellite images was variable, as some areas were covered more frequently than others. In order to account for this, the number of times each grid cell was "viewed" by the RADARSAT imagery was calculated for each winter season in order to standardize the density values by dividing the density values by the number of viewings. For each winter season, all the ridges identified that season were intersected with the grid in order to segment the ridges by grid cell. The length of each ridge segment in each grid cell was calculated. To obtain a standardized seasonal ridge density value for each cell, all the segment lengths in each grid cell were added together, then divided by the grid cell area and then divided by the number of times that grid cell was viewed that season. All of the identified ridges for each season were amalgamated to create an all-seasons mean. The ridge density values (total length of ridge segments in $\mathrm{m} \mathrm{m}^{-2}$ ) were divided into four categories $(<-0.5 \mathrm{SD},-0.5$ to $+0.5 \mathrm{SD},+0.5$ to +1.5 $\mathrm{SD}$, and $>+1.5 \mathrm{SD}$ ) according to their standard deviation from the composite mean. The maps were examined for patterns in the distribution of high and low ridge density areas.

\section{RESULTS AND DISCUSSION}

\section{Sea Ice Climatology and Trends}

The average weekly ice coverage and the spatial distribution of ice concentrations throughout the year in the Hudson Strait can be seen in Figure 3. Ice formation begins in early November in Foxe Basin, in the western sector of the Hudson Strait, and along the coastlines (Fig. 3A). By early December, the western half of the strait is covered by at least $5 / 10$ ice concentration or greater. The Hudson Strait reaches full coverage of $9 / 10$ ice concentration by 1 January, when there is also a wide band of landfast ice along the coast, especially along the islands and inlets of southern Baffin Island. The ice coverage begins to decrease in early May, when the landfast ice begins to break away from the coast, as visible along the northern coast of the strait. Ice clears out of the northern half of the strait before it leaves the southern half: by 25 June, there is only $1 / 10$ to $3 / 10$ coverage along the southern shore of Baffin Island, but there is still up to $9 / 10$ concentration in Ungava Bay, the last region to lose ice coverage. Here the ice becomes thick and rubbled as a result of prevailing winds and currents patterns, so it remains until early July (Markham, 1986). Figure 3G shows the annual cycle of ice coverage in $\mathrm{km}^{2}$.

A declining trend in ice coverage in the Hudson Strait, associated with later freeze-up and earlier breakup, can be seen in some of the winter months in the 1981-2013 sea ice climatology broken down on a monthly scale (Fig. 4). The decline is distinctly visible in the months of December and May and is statistically significant at the 95\% level for all months except January and February, for which the declining trend is significant at the $90 \%$ level. During these months, the ice has covered the full extent of the Hudson Strait. This finding is in agreement with later freeze-up and earlier breakup trends elsewhere in the Arctic as observed by Stroeve et al. (2014).

Ice freeze-up and breakup dates during the study period (1997-2012) are listed in Table 1. All seasons have freezeup dates that are the same as or later than the climatological mean, and all seasons except 2008-09 have breakup dates on or before the climatological mean. This observation agrees with the declining trends in Figure 4. However, the freeze-up and breakup dates within the study period are relatively consistent, though 2008-09 is notable for having a breakup date three weeks later than the study period mean. As well, the 2010-11 season had an extremely late freeze-up, as ice did not cover $50 \%$ of the region until the third week of January.

Temporal Analysis of Ridge Counts in the Hudson Strait, 1997 to 2012

As seen in Figure 5A, the overall mean annual ridge count was 110. The 2006-07 season had the highest mean count, with 231 ridges identified. The years 2000-01, 2001-02, 2004-05, and 2005-06 were also seasons 

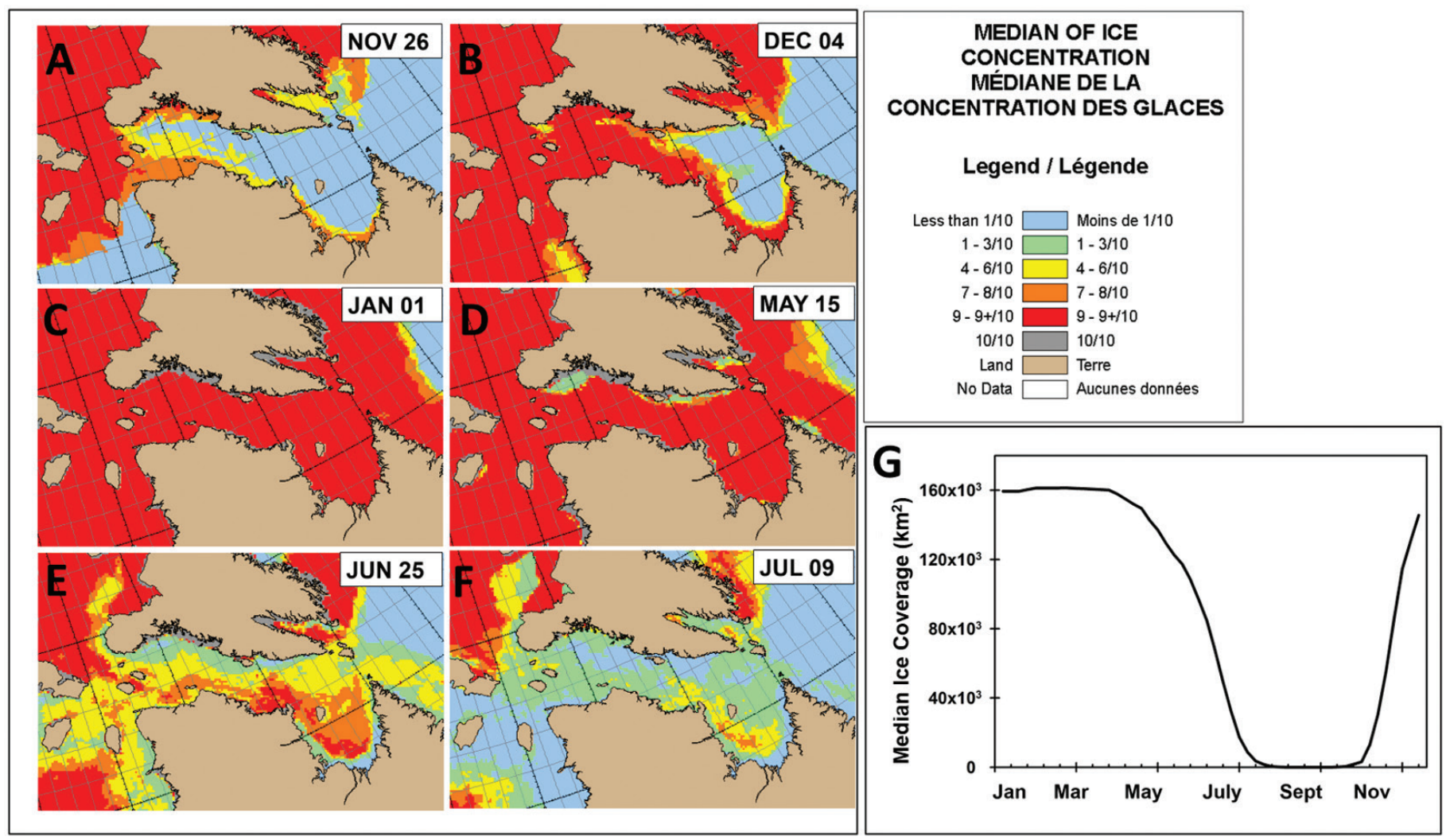

FIG. 3. Median ice concentration in the Hudson Strait on (A) November 26, (B) December 4, (C) January 1, (D) May 15, (E) June 25, and (F) July 9, based on a 30-year sea ice climatology for 1981-2010 (CIS, 2011). Panel (G) shows the annual ice coverage cycle in the Hudson Strait for 1981 -2010 (CIS, 2011 ).

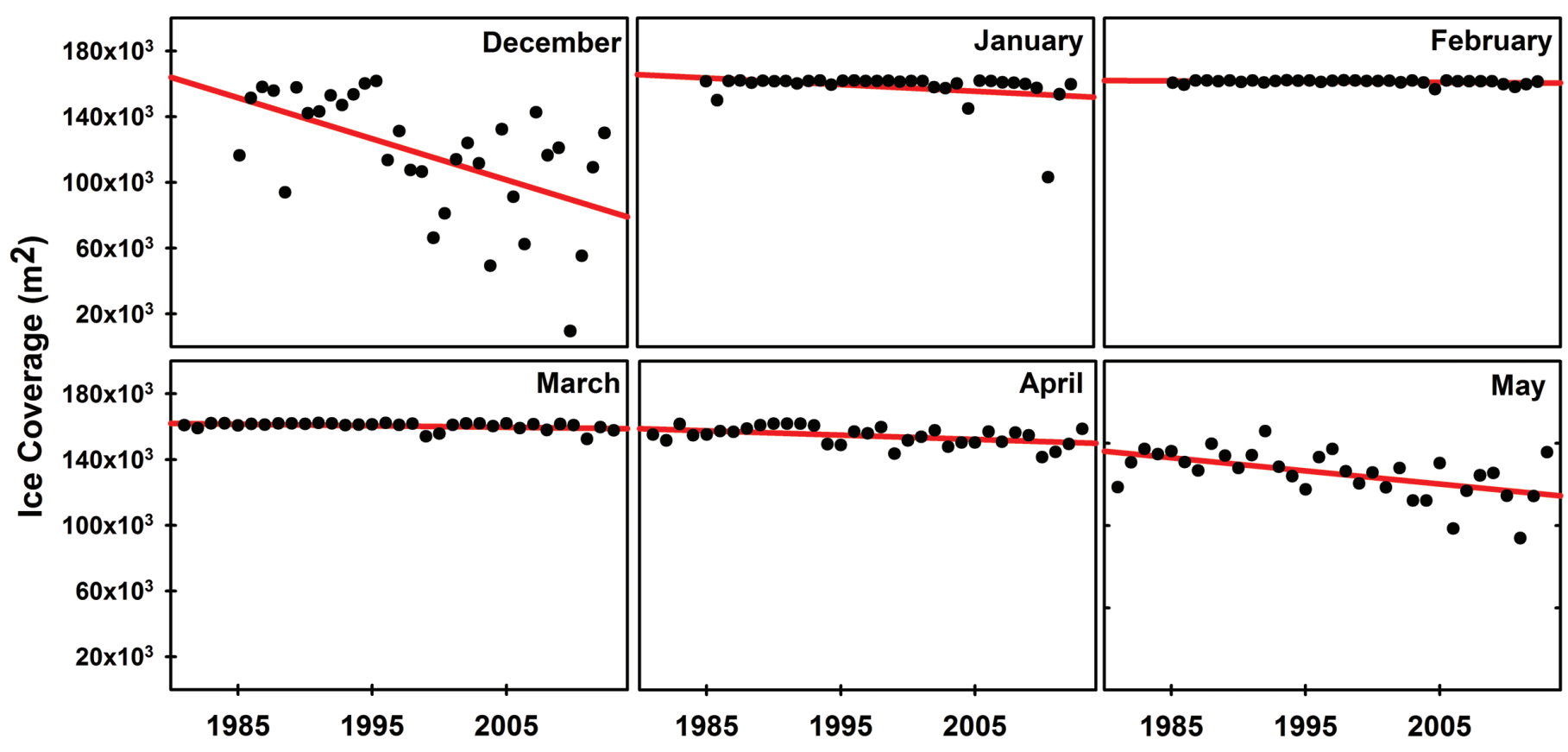

FIG. 4. Mean December-to-May ice coverage in the Hudson Strait from 1981 to 2013 (CIS, 2011).

with greater than average standardized ridge count. The 1998-99 season displayed the lowest mean count, with 39 ridges. The years $2008-09,2009-10$, and $2010-11$ are notable in that they were three winter seasons in a row with lower than average standardized ridge counts. The year $2003-04$ was also striking for having a lower than average seasonal standardized ridge count. The seasons were categorized as low ridge-density seasons (annual average less 


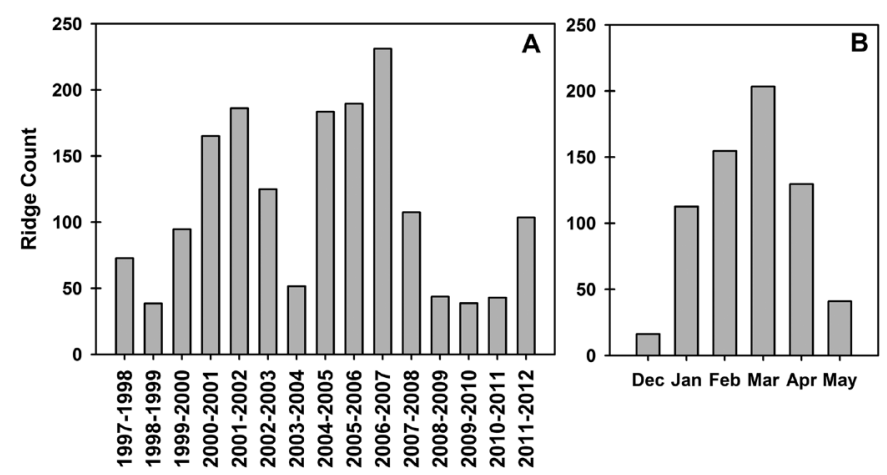

FIG. 5. (A) Mean annual standardized ridge counts in the Hudson Strait shipping corridor from 1997 to 2012; (B) Mean monthly standardized ridge counts from 1997 to 2012.

than 50 ridges per image), normal ridge-density seasons (annual average 51 to 149 ridges per image) and high ridgedensity seasons (annual average more than 150 ridges per image). The low ridge-density seasons (1998-99, 2003-04, $2008-09,2009-10,2010-11)$ and high ridge-density seasons $(2000-01,2001-02,2004-05,2005-06,2006-07)$ will be examined in greater detail in the Discussion. Indeed, there is a high interannual variability in the average number of identified ridges, but annual average values of ridge counts on the scale of the entire shipping corridor do not indicate any trend towards more or less ridging. Figure 6 shows the variability in ridge counts at the monthly scale. There is no trend towards more or less ridging at this scale either. Unsurprisingly, there is a much greater range in ridge counts in January, February, March, and April, when ice concentrations in the strait are higher, than there is in December and May, when there is less ice in the strait. Finally, when examining these results, it should be recalled that there is some uncertainty associated with the ridge counts given the differences in ridge width $(3-4 \mathrm{~m})$ and the image resolution $\left(200 \mathrm{~m} \mathrm{pixel}^{-1}\right)$. Thus, some of the smaller ridges may not have been visible or accounted for given their proximity to other ridges.

The mean monthly distribution of ridge counts for all seasons combined is displayed in Figure 5B. This figure shows that on a monthly basis, ridging was found to peak in March, with a mean of 203 ridges per image, which was followed by February (155), and April (130). The ridge count monthly distribution is shown for each individual season in Figure 7. Most of the seasons follow the average distribution, with ridge counts peaking in March. During the 2003-04 and 2008-09 seasons, which were two extremely low ridge-count seasons, ridge counts in February and March were almost identical. The low ridging seasons of 2003-04 and 2009-10 are also notable in that ridge counts peaked later than average, in the month of April.

Figure 8 shows the development of the ice coverage in the Hudson Strait in both the low ridge-count and the high ridge-count seasons. It is notable that in the high ridgecount seasons, the onset of ice formation is relatively consistent, whereas in the low ridge-count seasons there is a
TABLE 1. Freeze-up and breakup dates for the Hudson Strait. Freeze-up is defined as the date when ice first covers $50 \%$ of the Strait; breakup is the date when ice first covers less than $50 \%$ of the Strait (CIS, 2011).

\begin{tabular}{lcc}
\hline \hline Season & $\begin{array}{c}\text { Freeze-up week } \\
\text { number }\end{array}$ & $\begin{array}{c}\text { Breakup week } \\
\text { number }\end{array}$ \\
\hline $1997-1998$ & 50 & 26 \\
$1998-1999$ & 51 & 25 \\
$1999-2000$ & 51 & 25 \\
$2000-2001$ & 49 & 25 \\
$2001-2002$ & 50 & 26 \\
$2002-2003$ & 50 & 25 \\
$2003-2004$ & 52 & 26 \\
$2004-2005$ & 49 & 25 \\
$2005-2006$ & 51 & 22 \\
$2006-2007$ & 52 & 26 \\
$2007-2008$ & 49 & 26 \\
$2008-2009$ & 50 & 28 \\
$2009-2010$ & 50 & 24 \\
$2010-2011$ & 55 & 24 \\
$2011-2012$ & 52 & 25 \\
Mean (1997-2012) & 50.7 & 25.2 \\
Climatology mean (1981-2010) & 49.2 & 26.9 \\
\hline \hline
\end{tabular}

gap of almost eight weeks between the date when the season reached full ice coverage in 2008-09 and the corresponding date in 2010-11, when the ice in the strait did not reach full coverage until week 4 . Therefore, it is not surprising that no ridges were counted that season in December and January. However, late freeze-up cannot be the sole explanation for less ridging because in 2009-10, the previous season, there was also less than average ridging, but freeze-up occurred during week 49 , which is typical. The high ridge-count seasons appear to have more consistent breakups in terms of timing as well as ice loss.

\section{SPATIAL DISTRIBUTION OF RIDGE DENSITY IN THE HUDSON STRAIT, 1997-2012}

The spatial distribution of all the ridge densities from all seasons (1997-2012) and their mean are illustrated in Figure 9. In the mean map, clusters of higher ridge densities are grouped in the western and eastern zones of the shipping corridor. These include areas along the coast east of Deception Bay, between the Quebec mainland and Charles Island, and at the eastern end of the shipping corridor near the mouth of the Hudson Strait. Ridging along the coast is to be expected as this is where the mobile ice meets with the landfast ice and shear zones are formed. These are areas of heavy ridging and pose navigational difficulties for vessels attempting to cross them (P. Bourbonnais, pers. comm. 2014). Previous studies of ridging frequency have found different ridging regimes along the coast and farther offshore: typically ridge density increased with proximity to shore (Weeks et al., 1980, 1989; Wadhams, 1981). Ridging is also to be expected between Charles Island and the mainland, as ice typically travels from west to east in the Hudson Strait along with net volume of water (Straneo and Saucier, 2008b), so the ice there is being forced into a 


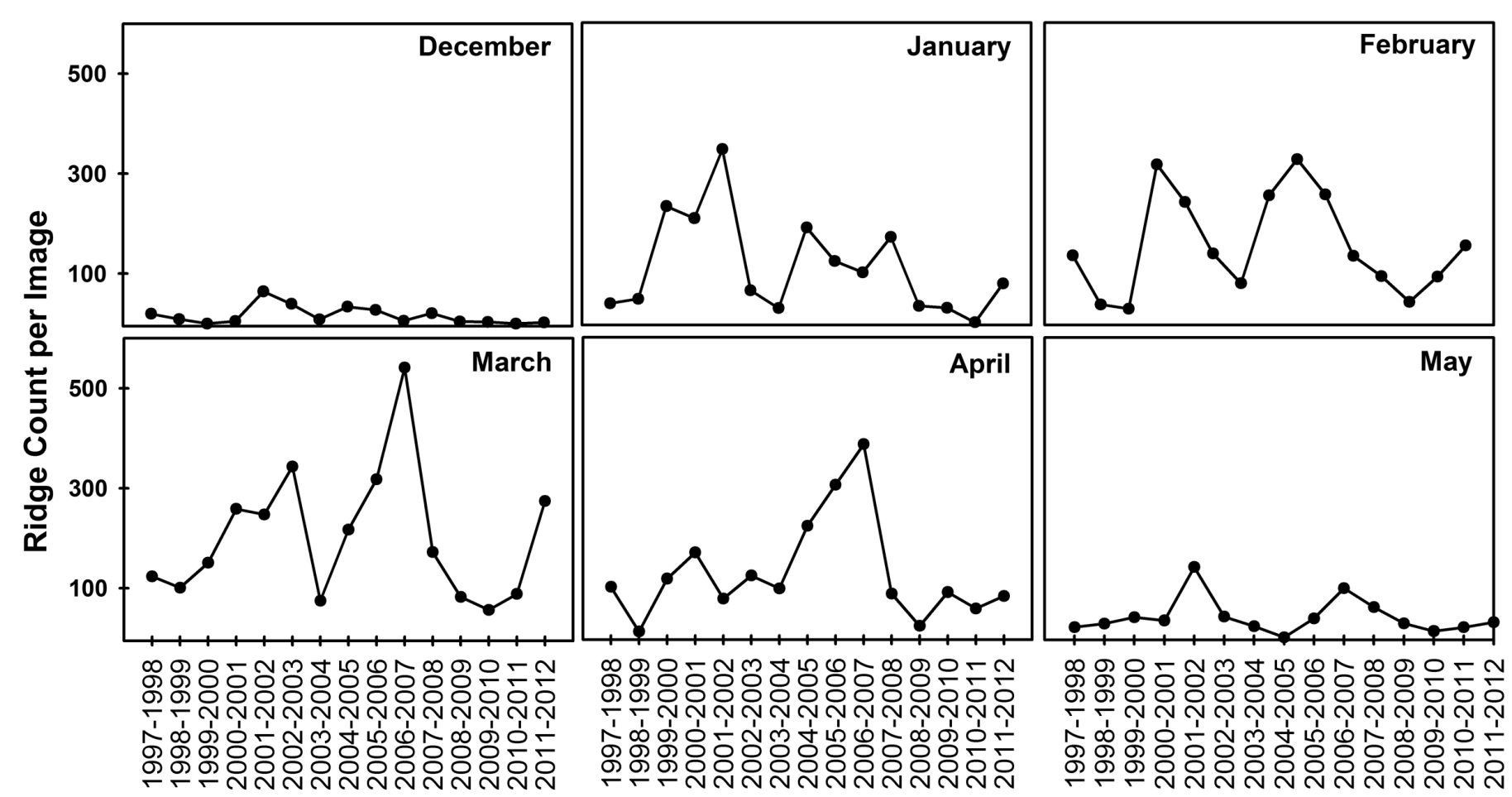

FIG. 6. Monthly standardized ridge counts within the Hudson Strait shipping corridor for individual seasons from 1997 to 2012.

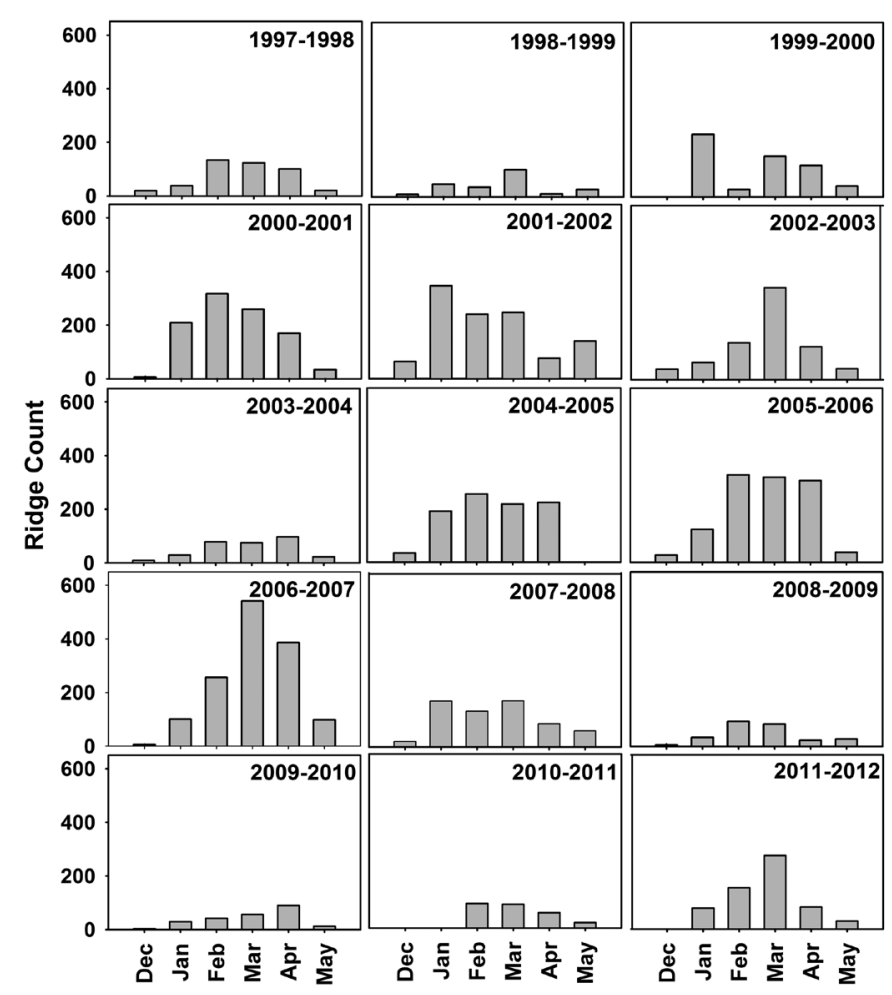

FIG. 7. Annual distribution of ridges for individual winters, 1997-2012.

bottleneck (Saucier et al., 2004). Ridging in the eastern end of the Hudson Strait is likely the result of ice moving north from Ungava Bay to meet the ice moving through the strait from west to east; where these two moving ice streams converge, they form ridges and pressured ice (Saucier et al., 2004). The lack of ridging in the middle of the corridor, along the southern coast of Baffin Island, is also to be expected because a polynya identified in that area is typically open all winter (CIS, 2011).

During most individual seasons, ridging is concentrated in the eastern and western zones of the study corridor, as is seen in the mean for all years in Figure 9. This pattern is very clearly seen in the $2002-03,2005-06$, and 2006-07 seasons, as well as the others. The 2006-07 season, identified as the season with the highest annual ridge count, had extensive amounts of ridging in the western half of the shipping corridor. The seasons of 1998-99 and 2003-04 both had less ridging than other seasons, with little ridging in either the eastern or the western parts of the strait. Similarly, 2008-09, 2009-10, and 2010-11 were seasons with lower than average ridge densities. The 2000-01, 2001-02, and 2007-08 seasons were anomalous, in that the majority of the areas with higher ridge density occurred in the central-western zone of the corridor, not in the far western or eastern zones of the corridor as is the case in the other seasons.

\section{ATMOSPHERIC CIRCULATION AND RIDGING IN THE HUDSON STRAIT}

Previous studies have shown that winds are an important driving factor in the creation of pressured ice and ridges, and geostrophic winds can explain most sea ice motion on short time scales (Thorndike and Colony, 1982; Kubat et 


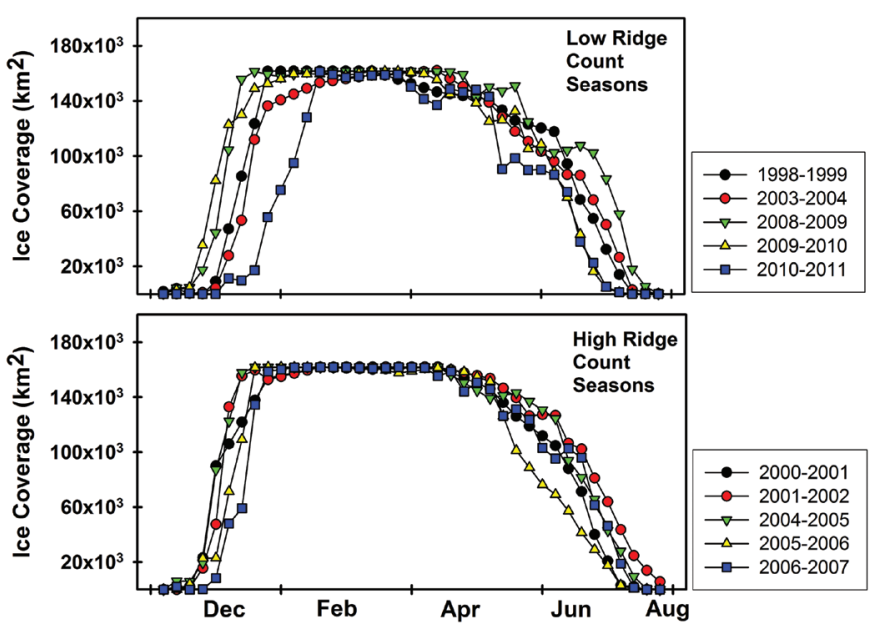

FIG. 8. Ice cover development in the Hudson Strait for seasons with (top) low ridge density and (bottom) high ridge density.

al., 2012). Typically, winds move from areas of high SLP to areas of low pressures so that the ice moves in parallel to the sea level pressure isobars (Thorndike and Colony, 1982). However, it should be noted that ice within $400 \mathrm{~km}$ of the shore has been found to be less influenced by geostrophic winds (Thorndike and Colony, 1982). SLP and wind anomalies, as well as one-time storm events, were therefore analyzed in this study to allow preliminary exploration of their possible correlations with ridge densities. As so little is known about the formation of ridges, it is useful to investigate whether better predictive measures for pressured ice could be developed in the future.

Typically, the Hudson Strait is influenced by a large low air pressure area over the North Atlantic, a strong high pressure area over Greenland, and a large area of high pressure over the Canadian Arctic (Drinkwater, 1986). The area of low pressure over the North Atlantic is what drives the prevalent northwesterly winds over the strait, which bring cold, Arctic air along with them (Drinkwater, 1986). However, anomalies in pressure patterns demonstrate the differences between seasons. Similarities are apparent between SLP anomalies during low ridge-density years although no significant correlation was found. Specifically, most low ridge-density seasons with the exception of 2008-09 were characterized by wide high-pressure anomalies over the Hudson Strait, a pressure pattern that could create winds which would facilitate the flow of ice through the strait. The SLP anomalies experienced during the high ridgedensity seasons were less consistent, and again no significant correlation was found. In some seasons, there was a large high SLP anomaly over the Atlantic Ocean and Hudson Strait similar to that seen in low ridge-density years, while in other cases large low pressure anomalies were centered over the Labrador Sea and influenced the Hudson Strait.

The role of one-time storm events in determining ridge density was also investigated. Fifty-three severe storm events, defined as times when the SLP dropped below
$960 \mathrm{mb}$ in the Hudson Strait, were identified from 1997 to 2012. December, when 20 of the 53 storm events occurred, was the stormiest month, but at that time there was insufficient ice in the Hudson Strait for ridges to form. Unfortunately, for most of the storm events later in the winter, there was not enough coverage by the satellite images immediately before and after the storm to determine its potential impacts. However, two storm events clearly increased pressure and the number of ridges in the Hudson Strait. The first took place on 23 February 2001 and the second on 31 January 2008. In both cases, evidence of increased ridging is apparent after the storm event (not shown). Therefore, it is likely that severe storm events could play a role in increasing pressure and ridging, but consistent image coverage is necessary to investigate this effect further. We require more detailed analysis, at a finer temporal and spatial scale, to understand the role of sea level pressure, one-time storm events, and winds in determining ridge density in the Hudson Strait.

\section{IMPLICATIONS FOR WINTER SHIPPING IN THE HUDSON STRAIT}

Currently, the Hudson Strait is being used year-round by an ice-strengthened vessel that services a mine in northern Quebec. Winter shipping in the strait may increase as proposed resource development projects move forward. Besetting events caused by pressured sea ice and heavy ridging can be very costly to the vessels traveling through the strait, both economically and environmentally.

This study has demonstrated that there are relatively consistent patterns in spatial ridge density distribution in the strait, as well as peak ridge periods throughout the winter. The ridging peak in March indicates that ship captains should prepare for slower voyages and a greater likelihood of becoming stuck or beset in the shipping corridor during that month. There is a consistent prevalence of ridges along the landfast ice near Deception Bay, where the contact between the landfast ice and the mobile ice of the strait forms a shear zone. This area is almost always heavily ridged in each of the studied seasons. Ship captains would need to approach the area with caution. The high density of ridging that occurs between Charles Island and the mainland of Quebec also appears consistently in many of the years studied. It is an example of a bottleneck area, where the ice is being pushed between the island and the mainland on its way eastwards through the strait. Areas of high density ridging would also be expected elsewhere in the strait where prevailing winds and currents are pushing ice through a narrow gap. Coastal geography can be used to predict potential areas of high sea ice pressure and ridge density. Finally, the high ridge density at the entrance to the strait in some seasons is also notable for vessels entering the strait. This situation does not occur every season, and it will take further research to understand why more ridges appear in some seasons than in others. Freeze-up 


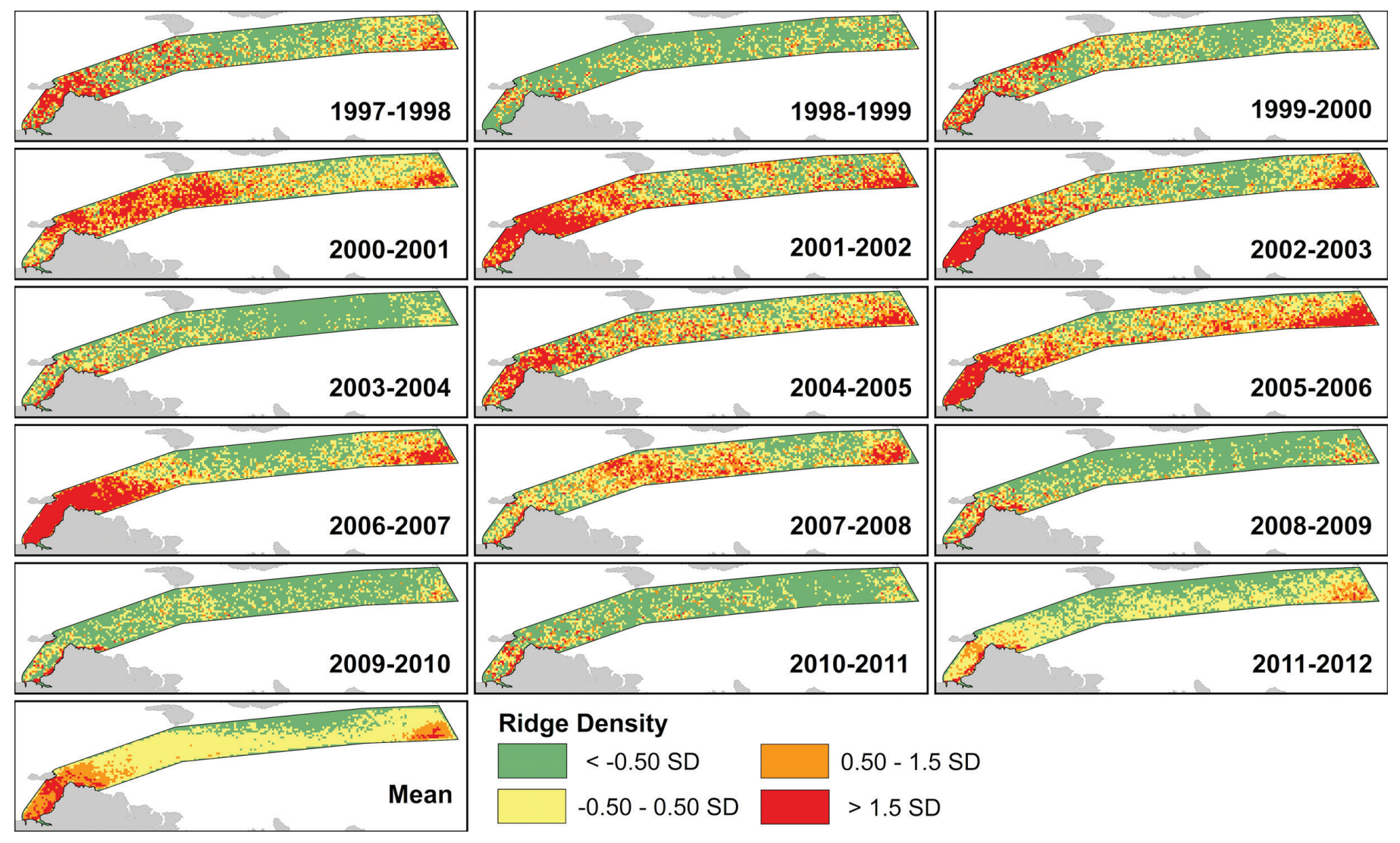

FIG. 9. Mean annual ridge density distribution each season along the corridor in the Hudson Strait, 1997-2012.

and breakup dates in the strait were relatively consistent throughout the study period, with a few outliers (the extremely late ice breakup in $2008-09$, and the extremely late freeze-up in 2010-11). This information is also important for ship operators, who can expect significant ice within the strait by week 51 and ice coverage that will continue until at least week 25 . The results of this research are useful for seasonal voyage planning and route selection. However, note that this was an exploratory analysis that contributes to the understanding of ridge formation. Continued research in this area is needed to develop models for real-time forecasting of pressured ice and the formation of ridges. Developing ridge prediction capabilities will aid in navigational decision making.

\section{CONCLUSIONS}

Pressured sea ice and ridges are extremely hazardous for ship operators. As a result, better understanding of the temporal and spatial extent of ridging is needed in order to improve the safety of winter shipping. Ships traveling through the Hudson Strait during the winter months have often encountered ridged ice and pressure. The observational method in this study, using RADARSAT images, provides an understanding of the temporal and spatial frequency and distribution of ridging.
The standardized ridge counts indicate no significant change over time in the number of ridges identified from the 1997-98 to the 2011-12 winter season but they varied greatly from season to season. However, there were notable patterns in the distribution of high ridge-density areas, with ridging peaking in the eastern and western zones of the shipping corridor. These distributions can be explained by the presence of shear zones between the mobile ice and the landfast ice, where ridging and pressure can occur, as well as bottlenecking, where the ice is forced to converge while being pushed between two land masses. Ice coverage development differs in seasons with differing ridge counts: low ridge count seasons showed more variable freeze-up and breakup dates than seasons with high ridge counts. An exploratory investigation into the possible connection between sea level pressure anomalies and ridge densities did not find conclusive correlations, but some consistencies were seen in the sea level pressure anomalies present during low ridgedensity years, and it was found that one-time storm events could play a role in increasing pressure and ridging patterns. Further investigations into these connections are needed.

Understanding patterns in basin-level ridge distribution is highly important for improving winter shipping navigation. This information can be used by ship operators during seasonal route planning to predict where and when ridges and hazardous ice conditions may be encountered in the Hudson Strait. However, real-time information and forecasts are also needed to promote safer shipping. 
The method used in this study could be used elsewhere in the Canadian Arctic to understand ridging patterns in preparation for the development of new winter shipping routes. This work could be built upon by attempting to automate the ridge identification process, which would greatly increase the speed at which the analysis could be performed. Understanding the conditions that cause ridging is also important, so correlations between ridging patterns and sea level pressure, air temperature, and currents should be undertaken. This work could improve our understanding of where ships have become beset in the past and aid in predicting where and when ridging might occur in the future. Additionally, it could be useful for validating the presence of ridges in high-resolution ice dynamics models.

\section{ACKNOWLEDGEMENTS}

The authors gratefully acknowledge Angela Cheng and Tom Zagon from the Canadian Ice Service for their knowledge and guidance in the areas of sea ice and remote sensing. We would also like to thank Fednav personnel for contributing insight and knowledge about winter shipping. Funding for this project was provided by the Natural Sciences and Engineering Research Council (NSERC), Marine Environmental Observation Prediction and Response Network (MEOPAR), and by the Environment, Society, and Policy Group at the University of Ottawa. Finally, we thank the anonymous reviewers who provided constructive commentary on the manuscript.

\section{REFERENCES}

Amundrud, T.L., Melling, H., and Ingram, R.G. 2004. Geometrical constraints on the evolution of ridged sea ice. Journal of Geophysical Research 109, C06005. http://dx.doi.org/10.1029/2003JC002251

Bradford, D. 1972. Sea ice pressures observed on the second "Manhattan" voyage. Arctic 25(1):34-39.

http://dx.doi.org/10.14430/arctic2939

Brigham, L. 2011. Marine protection in the Arctic cannot wait. Nature 478:157.

http://dx.doi.org/10.1038/478157a

CIS (Canadian Ice Service). 2011. Sea ice climatic atlas for the northern Canadian waters 1981-2010. Ottawa: CIS. 995 p. https://www.ec.gc.ca/glaces-ice/?lang=En\&n=4B35305B-1

Crane, R.G. 1978. Seasonal variations of sea ice extent in the Davis Strait-Labrador Sea area and relationship with synoptic-scale atmospheric circulation. Arctic 31(4):434-447. http://dx.doi.org/10.14430/arctic2671

Dierking, W., and Dall, J. 2007. Sea-ice deformation state from synthetic aperture radar imagery-Part I: Comparison of Cand L-band and different polarization. IEEE Transactions on Geoscience and Remote Sensing 45(11):3610-3622.

Drinkwater, K.F. 1986. Physical oceanography of Hudson Strait and Ungava Bay. In: Martini, I.P., ed. Canadian inland seas. New York: Elsevier Science. 237-260.
Gagnon, A.S., and Gough, W.A. 2005. Trends in the dates of ice freeze-up and breakup over Hudson Bay, Canada. Arctic 58(4):370-382. http://dx.doi.org/10.14430/arctic451

Gorbunova, K., and Shkhinek, K. 2015. Engineering properties of sea ice ridges in the Barents Sea in 2012-2014 years for evaluation of ice loads on offshore structures. Applied Mechanics and Materials 725-726:263-269.

http://dx.doi.org/10.4028/www.scientific.net/AMM.725726.263

Gough, W.A., and Houser, C. 2005. Climate memory and longrange forecasting of sea ice conditions in Hudson Strait. Polar Geography 29(1):17-26.

http://dx.doi.org/10.1080/789610163

Houser, C., and Gough, W.A. 2003. Variations in sea ice in the Hudson Strait: 1971 - 1999. Polar Geography 27(1):1 - 14 . http://dx.doi.org/10.1080/789610211

Johnston, M. 2001. Validation of RADARSAT imagery using in situ measurements from first year ridged ice. Proceedings of the 16th International Conference on Port and Ocean Engineering under Arctic Conditions, 12-17 August 2001, Ottawa, Ontario. 1129-1138.

Johnston, M., and Flett, D. 2001. First year ridges in RADARSAT ScanSAR imagery: Influence of incidence angle and feature orientation. Proceedings of the 4th International Symposium on Remote Sensing in Glaciology, 4-8 June 2001, College Park, Maryland.

Kalnay, E., Kanamitsu, M., Kistler, R., Collins, W., Deaven, D., Gandin, L., Iredell, M., et al. 1996. The NCEP/NCAR reanalysis 40-year project. Bulletin of the American Meteorological Society 77:437-471. http://dx.doi.org/10.1175/1520-0477(1996)077<0437:TNYRP> 2.0.CO;2

Kubat, I., and Sudom, D. 2008. Ship safety and performance in pressured ice zones: Captains' responses to questionnaire. Technical Report CHC-TR-056. Ottawa, Ontario: Canadian Hydraulics Centre, National Research Council of Canada. http://dx.doi.org/10.4224/20178990

Kubat, I., Babaei, M.H., and Sayed, M. 2012. Quantifying ice pressure conditions and predicting the risk of ship besetting. Proceedings from ICETECH 2012, 17-20 September 2012, Banff, Alberta. Paper No. ICETECH12-130-R0.

Kubat, I., Sayed, M., and Babaei, M.H. 2013. Analysis of besetting incidents in Frobisher Bay during the 2012 shipping season. Proceedings from the 22nd International Conference on Port and Ocean Engineering under Arctic Conditions, 9-13 June 2013, Espoo, Finland.

Kwok, R. 2014. Declassified high-resolution visible imagery for Arctic sea ice investigations: An overview. Remote Sensing of Environment 142:44-56. http://dx.doi.org/10.1016/j.rse.2013.11.015

Kwok, R., Cunningham, G.F., Zwally, H.J., and Yi, D. 2006. ICESat over Arctic sea ice: Interpretation of altimetric and reflectivity profiles. Journal of Geophysical Research 111, C06006.

http://dx.doi.org/10.1029/2005JC003175 
Leppäranta, M. 2005. The drift of sea ice, $1^{\text {st }}$ ed. New York: Springer-Verlag. 266 p.

Lipscomb, W.H., Hunke, E.C., Maslowski, W., and Jakacki, J. 2007. Ridging, strength, and stability in high-resolution sea ice models. Journal of Geophysical Research 112, C03S91. http://dx.doi.org/10.1029/2005JC003355

Marchenko, A.V. 2008. Thermodynamic consolidation and melting of sea ice ridges. Cold Regions Science and Technology 52(3):278-301.

http://dx.doi.org/10.1016/j.coldregions.2007.06.008

Markham, W.E. 1986. The ice cover. In: Martini, I.P., ed. Canadian inland seas. New York: Elsevier Science Ltd. 101-116.

Mårtensson, S., Meier, H.E.M., Pemberton, P., and Haapala, J. 2012. Ridged sea ice characteristics in the Arctic from a coupled multicategory sea ice model. Journal of Geophysical Research 117, C00D15.

http://dx.doi.org/10.1029/2010JC006936

Melling, H. 1998. Detection of features in first-year pack ice by synthetic aperture radar (SAR). International Journal of Remote Sensing 19(6):1223-1249.

http://dx.doi.org/10.1080/014311698215702

Montewka, J., Goerlandt., F., Kujala, P., and Lensu, M. 2015. Towards probabilistic models for the prediction of a ship performance in dynamic ice. Cold Regions Science and Technology 112:14-28.

http://dx.doi.org/10.1016/j.coldregions.2014.12.009

NEAS (Nunavut Eastern Arctic Shipping). 2014. Sailing schedule. Iqaluit: NEAS.

http://www.neas.ca/schedule.cfm

Obert, K.M., and Brown, T.G. 2011. Ice ridge keel characteristics and distribution in the Northumberland Strait. Cold Regions Science and Technology 66(2-3):53-64.

Pärn, O., Happala, J., Kõuts, T., Elken, J., and Riska, K. 2007. On the relationship between sea ice deformation and ship damages in the Gulf of Finland in winter 2003. Proceedings of the Estonian Academy of Sciences and Engineering 13(3):201-214.

Pizzolato, L., Howell, S.E.L., Derksen, C., Dawson, J., and Copland, L. 2014. Changing sea ice conditions and marine transportation activity in Canadian Arctic waters between 1990 and 2012. Climatic Change 123(2):161 - 173. http://dx.doi.org/10.1007/s10584-013-1038-3

Saucier, F.J., Senneville, S., Prinsenberg, S., Roy, F., Smith, G., Gachon, P., Caya, D., and Laprise, R. 2004. Modelling the sea ice-ocean seasonal cycle in Hudson Bay, Foxe Basin and Hudson Strait. Climate Dynamics 23(3):303-326. http://dx.doi.org/10.1007/s00382-004-0445-6

Scheuchl, B., Flett, D., Caves, R., and Cumming, I. 2004. Potential of RADARSAT-2 data for operational sea ice monitoring. Canadian Journal of Remote Sensing 30(3):448-461.

Smith, L.C., and Stephenson, S.R. 2013. New Trans-Arctic shipping routes navigable by mid-century. Proceedings of the National Academy of Science 110(13):E1191 -E1195. http://dx.doi.org/10.1073/pnas.1214212110

Stephenson, S.R., Smith, L.C., Brigham, L.W., and Agnew, J.A. 2013. Projected 21st-century changes to Arctic marine access. Climatic Change 118(3):885-899.

http://dx.doi.org/10.1007/s10584-012-0685-0
Stewart, D.B., and Lockhart, W.L. 2005. An overview of the Hudson Bay marine ecosystem. Canadian Technical Report of Fisheries and Aquatic Sciences 2586. 487 p.

Straneo, F., and Saucier, F.J. 2008a. The Arctic-Subarctic exchange through Hudson Strait. In: Dickson, R.R., Meincke, J., and Rhines, P., eds. Arctic-Subarctic ocean fluxes: Defining the role of the northern seas in climate. Dordrecht: Springer Science. 249-261.

http://dx.doi.org/10.1007/978-1-4020-6774-7_11

__ _ 2008b. The outflow from Hudson Strait and its contribution to the Labrador Current. Deep Sea Research Part 1 55(8):926-946.

http://dx.doi.org/10.1016/j.dsr.2008.03.012

Stroeve, J.C., Markus, T., Boisvert, L., Miller, J., and Barrett, A. 2014. Changes in Arctic melt season and implications for sea ice loss. Geophysical Research Letters 41(4):1216-1225. http://dx.doi.org/10.1002/2013GL058951

Strub-Klein, L., and Sudom, D. 2012. A comprehensive analysis of the morphology of first-year sea ice ridges. Cold Regions Science and Technology 82:94-109.

http://dx.doi.org/10.1016/j.coldregions.2012.05.014

Sulsky, D., and Peterson, K. 2011. Towards a new elasticdecohesive model of Arctic sea ice. Physica D: Nonlinear Phenomena 240(20):1674-1683.

http://dx.doi.org/10.1016/j.physd.2011.07.005

Thorndike, A.S., and Colony, R. 1982. Sea ice motion in response to geostrophic winds. Journal of Geophysical Research 87(C8):5845-5852.

http://dx.doi.org/10.1029/JC087iC08p05845

Timco, G.W., and Burden, R.P. 1997. An analysis of the shapes of sea ice ridges. Cold Regions Science and Technology 25(1):65-77. http://dx.doi.org/10.1016/S0165-232X(96)00017-1

Timco, G.W., Croasdale, K., and Wright, B. 2000. An overview of first-year sea ice ridges. Technical Report HYD-TR-047. Ottawa, Ontario: Canadian Hydraulics Centre. http://doi.org/10.4224/12327286

Timco, G.W., Gorman, B., Falkingham, J., and O'Connell, B. 2005. Scoping study: Ice information requirements for marine transportation of natural gas from the High Arctic. Technical Report CHC-TR-029. Ottawa, Ontario: Canadian Hydraulics Centre. http://dx.doi.org/10.4224/12340988

Tivy, A., Howell, S.E.L., Alt, B., McCourt, S., Chagnon, R., Crocker, G., Carrieres, T., and Yackel, J.J. 2011. Trends and variability in summer sea ice cover in the Canadian Arctic based on the Canadian Ice Service Digitial Archive, 1960-2008 and 1968-2008. Journal of Geophysical Research 116, C03007. http://dx.doi.org/10.1029/2009JC005855

Vakulenko, A.M., and Bolshev, A.S. 2015. Loads from ice ridge keels - Analytical vs. numerical. Applied Mechanics and Materials 725-726:229-234.

Valdez Banda, O.A., Goerlandt, F., Montewka, J., and Kujala, P. 2015. A risk analysis of winter navigation in the Finnish sea areas. Accident Analysis and Prevention 79:100-116. http://dx.doi.org/10.1016/j.aap.2015.03.024 
Vesecky, J.F., Smith, M.P., and Samadani, R. 1990. Extraction of lead and ridge characteristics from SAR images of sea ice. IEEE Transactions on Geoscience and Remote Sensing 28(4):740-744.

Wadhams, P. 1981. Sea ice topography of the Arctic Ocean in the region $70^{\circ} \mathrm{W}$ to $25^{\circ} \mathrm{E}$. Philosophical Transactions of the Royal Society A: Mathematical, Physical and Engineering Sciences 302(1464):45-85.

-. 2000. Ice in the ocean. London: Gordon and Breach Science Publ. 351 p.

Weeks, W.F. 2010. On sea ice. Fairbanks: University of Alaska Press. 664 p.

Weeks, W.F., and Kovacs, A. 1970. On pressure ridges. CREEL Technical Report IR505. Hanover, New Hampshire: Cold Regions Research and Engineering Laboratory. 59 p.
Weeks, W.F., Tucker, W.B., III, Frank, M., and Fungcharoen, S. 1980. Characterization of surface roughness and floe geometry of sea ice over the continental shelves of the Beaufort and Chukchi Seas. In: Pritchard, R.S., ed. Sea ice processes and models. Seattle: University of Washington Press. 300-312.

Weeks, W.F., Ackley, S.F., and Govoni, J. 1989. Sea ice ridging in the Ross Sea, Antarctica, as compared with sites in the Arctic. Journal of Geophysical Research 94(C4):4984-4988. http://dx.doi.org/10.1029/JC094iC04p04984

Xue, C., Wen, X., Dong, Q., and Wang, X. 2011. Tracking the dynamic sea ice process with RADARSAT-2 imagery. Proceedings of the Twenty-first (2011) International Offshore and Polar Engineering Conference, 19-24 June 2011, Maui, Hawaii. 986-991. 